\title{
“NARODNE NOVINE": GENRE, THEMATIC AND VISUAL TRANSFORMATION 1949-2019
}

\begin{abstract}
The importance of local media is indisputable for media theorists and media practitioners, despite the widespread globalization. Although electronic media has the largest audience, while online media is constantly expanding, the traditional print media is still surviving and they influence the political and social life of local communities. "Narodne novine" [English: The People's Newspaper] are a daily news and political newspaper with the longest publication time in south-eastern Serbia. By using the quantitative and qualitative content analysis, as well as the comparative and synthetic research method, the authors investigate how this newspaper has transformed in relation to genre, and in thematic and visual terms during the two socially and historically different periods - in the socialist and transitional period. The research corpus consists of 63 articles from two editions of "Narodne novine" - the newspapers published on May $1^{\text {st }} 1949$ (28 articles) and 70 years later, on May $1^{\text {st }} 2019$ (35 articles).
\end{abstract}

Key words: local media, publishing, "Narodne novine", Socialism, transition

\section{Introduction}

The fear that the development and expansion of new media, twill cause the old media disappear, was refuted by the reality, which is evidenced by the fact that the emergence and improvement of new media has actually led not to the disappearance of the old media, but rather to their transformation and adaptation, both to the new media features and to the needs of the audience. It is always necessary to analyse and observe media transformation in the broader social context possible, as well as to keep in mind that the media and the social community are two closely connected and inseparable categories that constantly influence one another. Even though electronic media has the largest audience, while online media is constantly expanding, the traditional print media are still being published and they influence the political and social life of local communities. Their importance is beyond question, because in addition to informing the audience on local issues and monitoring local decisionmakers, local media should continuously initiate civic awareness decentralization and contribute to the well-being of communities through the public interest activities. That is why it is very important that the local media do not serve the holders of

\footnotetext{
${ }^{1}$ Received September 2019 / Accepted May 2020

${ }^{2}$ E-mail: marija.vujovic@filfak.ni.ac.rs
} 
political or economic capital, which happens very frequently in Serbia due to their poor economic status.

The question that bothers both media theorists and practitioners is - how can local print media survive in the market. It is actually the search for the answer to this question that is the catalyst for the transformation of a print media in order to improve the competitiveness in the digital environment and in the local media market. When analysing local print media in Serbia, it is important to emphasize that the Serbian media system is characterized by a great media dependence on the State and by an underdeveloped media market, even though due to the need for the State to withdraw from ownership in media ${ }^{3}$, the 2014 Law on Public Information and Media required that all state-owned media must be privatized in 2015. Media privatization in Serbia officially ended on October 31 of that year, which caused many local stations to shut down. An important step in the media transition is to adopt a set of media laws ${ }^{4}$. However, such laws are very rarely implemented in practice, as evidenced by the May 2019 European Commission Progress Report on Serbia 5 . There is no complete freedom of speech in Serbia, there are still threats to and violence against journalists, independent regulatory agencies are not doing their job, and there is a lack of transparency in ownership structures and in media funding from State funds, especially at the local level.

The global media situation is becoming increasingly complex due to the development of new media technologies which make the audience require new types of content that bring brief information and instant gratification.

However, after the "slow" print media has realized that they cannot win the battle against the Internet, they began to search for their own characteristics which would give them a comparative advantage over the new media.

In this paper, the authors investigate journalistic practices in the "Narodne novine" newspaper during the two socially and historically different periods - the socialist and transitional period, in order to point to the characteristics and specifics of the transformation of local print media. The goal is to investigate how the "Narodne novine" newspaper has transformed itself in relation to genre, and in thematic and visual terms.

The first chapter of the paper is called The Importance of Local Media, and it highlights the importance of local print media for community development and its

\footnotetext{
${ }^{3}$ The 2002 Broadcasting Law requried the withdrawal of the state from the media ownership, that is, asked for their capital to be sold throughout Serbia at public auctions.

${ }^{4}$ Some of the laws governing the media are: the Law on Public Information and Media, available at: http:// www.parlament.gov.rs/upload/archive/files/cir/pdf/zakoni/2014/2511-14.pdf, The Law on Electronic Media, available at: http://www.parlament.gov.rs/upload/archive/files/cir/pdf/zakoni/2014/2512-14. pdf, The Law on Public Service Broadcasting, available at: http://www.parlament.gov.rs/upload/archive/ files/cir/pdf/zakoni/2014/2513-14.pdf, The Law on Advertising, available at: http://www.paragraf.rs/ propisi/zakon_o_oglasavanju.html, Copyright and Related Rights Act, available at: http://www.paragraf. rs/propisi/zakon_o_autorskom_i_srodnim_pravima.html (Accessed August 20, 2019).

5 Available at: http://www.mei.gov.rs/upload/documents/eu_dokumenta/godisnji_izvestaji_ek_o_ napretku/20190529-serbia-report_SR_-_REVIDIRANO.pdf (Accessed August 20, 2019).
} 
democracy; the next chapter is "Narodne novine" and Socialism, which describes the historical development of this newspaper in the post-war period, followed by the chapter "Narodne novine" and the Transition Period giving an overview of this newspaper in the aftermath of democratic changes; the next chapter is called the Methodological Framework, followed by the Results of the Research and Discussion, and finally, the Conclusion, which draws attention to and expands the social significance of the research conducted.

\section{The importance of local media}

Local media are an indispensable participant of citizens' social and political life, as they represent the primary source of information from local communities and significantly affect the judgment and decision-making by individuals. "Local media are an element of a pluralistic society, they are the key institutions of the micro public sphere and often play the role of the local government controller," says Mihajlov-Prokopovic (2014:1), adding that their importance in modern democratic society is confirmed by the principles of European media policy which requires the countries to promote pluralism as well as to prevent unlawful media concentration. Beside this,"these media have an important role to play in promoting the quality of public life in local communities" (Milivojevic and Mihajlovic, 205: 11). Not only are the local media important, but they are also more important than the "big" media, because the information they provide is more concrete, closer to citizens and their everyday problems.

Studies dealing with the local media are scarce. One of them was conducted in the Netherlands, researching a local television audience. The results have shown that people expect the local media to do seven things: (1) provide relatively diverse, reliable, timely and unbiased background information on local community events; (2) promote social integration by helping people to be present in their local community; (3) inspire people and be an example to others; (4) ensure representation of different groups in the community; (5) increase the understanding of local communities for different groups; (6) be a form of local memory or a chronicle of local events; and, (7) contribute to social cohesion, to a sense of belonging to the locale (Costera Meijer, 2010 according to Nielsen, 2015:11).

Local print media are not the most widely read today, but they have the longest tradition and a significant influence. "From small rural communities covered by weekly newspapers to larger cities covered by their daily newspapers, the newspapers in general are an integral part of local life, with their journalists who document both the everyday events from and the monumental ones, who publish local discussions and more or less closely follow those in positions of power" (Nielsen, 2015:1). Nilsen believes that the biggest issues that local media, especially print media are facing are the decrease in print readers, decrease in advertising and general revenue, as the digital growth cannot yet make up for what has been lost on the print media 
side. In Serbia, commercial local media are also faced with problems. The financially unenviable position of local media is influenced by a number of factors, including the shift of advertisers to both national channels and the online sphere, as well as the insufficient economic power of local advertisers. Therefore, "The local media in the transition countries are barely surviving. The markets in these countries are mostly underdeveloped and the scarce advertising goes to large broadcasters" (MihajlovProkopović, 2014: 3). This issue is made even worse by the possible association of advertisers with certain political structures, which in this way may indirectly influence editorial policy, and make the role of local stations pointless ${ }^{6}$. Radojkovic claims that "... the mass media in Serbia are below the level considered average by the European Union. In addition to this, among the underdeveloped mass media, the local media are the most underdeveloped" (Radojković, 2007: 49). Several features of the local mass media are highlighted by the author: technical and productionbased inferiority, low readership (Serbia has one of the lowest daily newspaper readership indices in Europe, especially regarding local newspapers), the economic unsustainability of the mass media, media piracy, disregard for legal norms, lack of foreign investment (Radojković, 2007: 49-51).

Under such economic and political circumstances, the local media, although crucial for the cohesion of the community, barely survive since they are financially unsustainable and are forced to apply for co-financing ${ }^{7}$ using the funds from the local or state budget, or from some foreign donors. However, this model of co-financing also does not guarantee that there will not be another (potential) source of funding, and has been widely abused in practice. The biggest issues are incomplete legislation, insufficient transparency of the process, insufficient expert committees, lack of evaluation of approved projects and the process itself, undefined minimum of funds that should be allocated from the budget, lack of sanctions for lapses in procedures and committees' work ${ }^{8}$. Southern and Eastern Serbia region is especially at risk, since being the poorest and most underdeveloped region of the country?

Numerous socio-economic issues hamper the development of the region, which is why the role and importance of local media must be greater. Because, "Modern

\footnotetext{
${ }^{6}$ For more details please see the 2011 document by the Anti-Corruption Council of the Government of the Republic of Serbia, entitled The Report on Pressures and Control over the Media in Serbia.

${ }^{7}$ The possibility for the media to be funded from the republic, provincial or local budgets was provided by the Law on Public Information and Media of 2014, which defined the public media project cofinancing in order to preserve the public interest in the media.

${ }^{8}$ These conclusions were outlined in the White Paper of the Competitive Co-Financing of Public Interest in the Sphere of Public Information, published on the basis of a one-year study (April 2015-April 2016) conducted by the The Coalition of Media and Journalists' Associations. Available at: http://www.ndnv. org/wp-content/uploads/2016/06/BelaKnjigaWEB.pdf (Accessed August 20, 2019).

${ }^{9}$ Based on the data provided by the Statistical Office of the Republic of Serbia presented in the publication Regions in the Republic of Serbia in 2017, the region of South and Eastern Serbia has the lowest share in the gross domestic product of the Republic of Serbia, the lowest percentage of employed population and the highest percentage of the unemployed and inactive population, according to http://www.stat.gov.rs/ media/3698/g201826001.pdf (Accessed August 20, 2019).
} 
society seeks to make local media better and thus enable public debate on the most important issues of a particular community, that is, make its citizens capable and competent to participate in or influence the decisions to be made" (Veljanovski, 2017: 9). The role of local media is to spread democracy and promote social responsibility, in addition to informing citizens. "Narodne novine" in Nis has been trying to do this for seven decades.

\section{3. "Narodne novine" and Socialism}

The post-war period is a turning point in the history of Nis's print media. Socialism can be considered the golden age of the print media in Nis.

"From October 16, 1944, when the first newspaper was printed in Nis, and until the end of 1971, the print press in Nis had expanded on an unprecedented scale. Under those new socialist conditions, almost thirty years after the liberation, a great number of newspapers and magazines were published in Nis. It was during this period when the print media and journalism in general flourished, that numerous newspapers, magazines, school and factory papers, newsletters and publications by professional associations and institutions were published." (Mirčetić, 1972:107).

"Narodne novine", which was then called "Glas slobodnog Nisa" [English: The Voice of the Free Nis] was launched in the then Democratic Federal Yugoslavia in October $1944^{10}$. According to Dragoljub Mircetic (1972), after the liberation of Nis in World War II on October 14 1944, the printing company was immediately returned to Nis and became fully operational in two days when the printing started. The fact that it was the printing company, along with the brick factory "Laf", that was the first commercial enterprise to start working after the liberation, proves that local media was very important at that time. At that time, 25 workers were employed at this printing office. As early as October 18, 1944, the first issue of the "Glas slobodnog Nisa" was published ${ }^{11}$, only two pages. After four issues, and after the "confiscation and nationalization, the printing press turns into a printing company "Narodni list" [English: "People's Daily"] (Mircetic, 1972: 107), thus the following newspaper issue in the free and socialist Nis was published under the name "Narodni list". The first such issue was published on October 21, 1944, and was being printed until May $1^{\text {st }} 1949$. According to the information obtained from the "Nis Press - from 1871 to 1971", this newspaper was the Body for the District Committee of the National Liberation Front of the Nis District, and numerous experienced journalists worked there from the very beginning. One of the issues that stood out was the issue number

\footnotetext{
${ }^{10}$ The Democratic Federal Yugoslavia was established at the Second Session of the Anti-Fascist Council for the National Liberation of Yugoslavia (AVNOJ) in 1943. In 1945, the country changed its name to the Federal People's Republic of Yugoslavia, and since the adoption of the Constitution in 1963 it had been called the Socialist Federal Republic of Yugoslavia, until 1991 when its dissolution began.

11 Source: https://www.juznevesti.com/Drushtvo/69-rodjendan-Narodnih-novina.sr.html (Accessed August 20, 2019).
} 
8 of November 7,1944 , which was dedicated to the $27^{\text {th }}$ anniversary of the Great October Socialist Revolution," says Mircetic (1972: 108).

Although the first issues of the "Narodni list" did not specify the names of the editors, it was possible to find out that until September 1945 the following editors were in charge: Stojiljko Stojiljković, Slobodan Ivanović, Branislav Ćirić and Svetozar Ljubenović. On the $1^{\text {st }}$ of May 1947, "Narodni list" became the Body of the City Committee of the Nis National Front (Mirčetić, 1972: 107).

As of May $1^{\text {st }} 1949$, this newspaper has received the name most widely known to the current readership - "Narodne novine", and were sold at a price of 2 dinars per copy. In 1949, they were published as the Body of the Regional Committee of the People's Front of the Nis region, which was also the publisher of the newspaper. After that, "Narodne novine" became the Body of the City Committee of the Nis People's Front, then on September 1, 1955 the Body of the District Committee of the Socialist Union of Nis, and then the Body of the City Committee of the Socialist Alliance of Nis (Mirčetić, 1972: 107). That year was marked by the Third Plenum, when the state policy was changed, meaning that the USSR model was abandoned, and gradual liberalization in all areas of life was initiated. The influence of the West was growing, which included the development of print media. According to Janjetovic, the largest number of newspapers in socialist Yugoslavia were published in central Serbia, excluding Kosovo and Metohija and Vojvodina, but despite the large number of newspapers, Yugoslavia was in the last place in Europe regarding print media reading, with less than one hundred newspapers per one thousand people (Janjetović, 2011: 85).

As part of the "Narodne novine" publishing company, managed by Milos Bajagic at the time, "Narodne novine" began to be published as a daily from January 1, 1971. The newspaper was not published only on Sundays, while every Saturday a "Cultural Page" was published, containing two to four pages of text on Nis culture and history. The editor-in-chief of the newspaper at the time was Dragoljub Jankovic. In addition to "Narodne novine", this publishing company also published the weekly called "The magazine of Youth 68", and also owned the Special Issues Editorial Board. "When this newsletter first started to be published as a daily, it was under constant scrutiny of many watchful and conscientious eyes. They were often criticized, especially by senior executives," says Slobodan Krstic (2016: 86). That is why the editor-in-chief of "Narodne novine", Dragoljub Jankovic-Jenki "held the reins". "He shied away from any aphorism written by Timosenko Milosavljevic which could provoke various associations "(Krstić, 2016: 86). Jankovic was the editor-in-chief of Pirot "Sloboda" [English: Freedom], an associate of Radio Nis, and from 1955 to 1965 a journalist for "Narodne novine", where he began as a journalist for the cultural section. From 1965 to 1973, Janković was also the correspondent of Politika from Nis, and from 1970 to 1973 he was the editor-in-chief of "Narodne novine". During this period, he was also the director. In his monograph on "Narodne novine" called "Newspapers and Journalists" [Serbian: Novine i novinari], Krstic describes him as a journalist first, then a theatre critic, a cultural worker, a writer and a cultural worker. 
Djokica Jovanovic says that "Narodne novine" was a promoter of both ideological and propaganda interests and messages, as well as a defender of truth and authentic public interest, and that despite the critical attitude regarding the degree of professionalism of the journalists and editors of "Narodne novine", one cannot be indifferent to the fact that for the last half a century, "Narodne novine" has been "the most important factor in the information system of the city and this part of Serbia" (Krstić, 2016: 11). Jovanovic confirms that everything that is characteristic of the print media was also happening in "Narodne novine", and that journalists, under the constant pressure of the political establishment, often had to conform to the current ideological demand (Krstić, 2016: 11).

With regard to media systems in socialist countries, there were two models of information-communication systems according to Radojkovic,: the state/party model and the self-governing/socialist model, both being the part of the country establishment (Radojković, 1984). Private newspapers could not be published in socialism. One of the main features of Yugoslav socialism is media monopoly, control of the press and the public sphere. "In spite of the many freedoms enjoyed by the Yugoslav socialist society today thanks to the doctrine of self-government, there is still the continuous possibility of a return to totalitarianism [...] Because, despite the self-government, all channels of information and all permissible social organizations are under the control of the League of Communists; they are, therefore, in the Communist party's hands. And any one-party system, no matter what else may be said about it, is a kind of subcategory of Stalinism." (Mihajlov, 1968: 328-337 according todedi Dedić, 2009: 163).

\section{4. "Narodne novine" and transition}

After the collapse of this system, the media became part of a dual system commercial and public during the transition period. Public Service Broadcasting consists of the Radio and Television of Serbia and Radio and Television of Vojvodina, while all other electronic media are commercial. Print media are mostly privately owned. The first Serbian privately owned newspaper was the weekly "Nedeljni telegraf" [English: "Weekly Telegraph"], founded in 1994. It was founded by Slavko Curuvija together with Momčilo Đorgović, and two years after that, in 1996, they founded the first private daily newspaper in Serbia called "Dnevni telegraf" [English: "Daily Telegraph"] ${ }^{12}$. Despite the privatization of the media, the state has not completely relinquished ownership of some print media. “... The state and state institutions are co-owners of three significant publishers - Novosti (37\%), Politika newspaper and magazines (50\%) and Dnevnik holding (45\%)" (Matić, 2012: 177).

Veljanovski calls the new media systems - media systems in transition (Veljanovski, 2009:364). In this context, the term transition means to abandon the socialist system in some European countries. Democracy, parliamentary pluralism

\footnotetext{
${ }^{12}$ Data available at: https://sh.wikipedia.org/wiki/Slavko_Ćuruvija (Accessed August 20, 2019).
} 
and a capitalist-type market economy are becoming dominant. This process was generally complex and, in Serbia, exacerbated by the war in the former Yugoslavia and the sanctions.

"Narodne novine" is also a part of the media system in transition, and its tradition has been maintained to this day. After 70 years of publication under the same name, it is the only daily newspaper south of Belgrade. This daily was privatized in mid-2006, when it became part of a media conglomerate owned by the brothers Vidosav and Tomislav Radomirović. The newspaper was sold at a public auction for 16.609.000 dinars (Tomić, 2007: 66). Opinion was divided as to whether this was a successful privatization. The new owner was pleased: "The last ten years have proven that it has been a successful privatization because it has allowed the daily newspaper to run smoothly," as stated in a 2016 article published on the Belami web portal ${ }^{13}$ marking the publication anniversary of "Narodne novine". However, the experts are dissatisfied. Slavica Stojanovic, the editor of the news desk of this newspaper talked about the most current data on the financial, social and technological status, on the relation to the public interest, capacities and plans for the online edition, and on the development strategy of "Narodne novine"14, for the needs of the scientific project Local Media of the Nisava District in the Digital Age organized by the Department of Communication and Journalism at the Faculty of Philosophy, University of Nis. At that moment, "Narodne novine" had 35 employees. They are financed both from providing commercial services - advertising, and with funds received at the co-financing grant competitions for the media content of public interest. Stojanovic points out that the local advertising market for "Narodne novine" is relatively extensive, because it covers the entire region of south-eastern Serbia, thus going beyond the Nisava district area. However, the main issue is that marketing agencies own most of the market at the state level. The editor could not provide us with the information on the circulation, but she said that "Narodne novine" reaches all institutions, which has been a tradition from the time of the Socialist Federal Republic of Yugoslavia. Namely, almost all the city institutions were subscribed to this newsletter back then, and things are similar even today. On the one hand this is good, because of the impact they are making, while on the other hand it is not, because it reduces sale at the newsstands. This means that one newspaper is read by many people, so the rating is much higher than the circulation. The website has further increased readership but also decreased sales of the print edition, Stojanovic points out. "Narodne novine", in part, receives the funds necessary at the co-financing grant competitions at the city of Nis level, and of all the municipalities that this newspaper reports about. They are being allocated the funds from the budget of the City of Nis and city municipalities for the fourth year, ever since the media project financing began. Due to the small amount of money that the municipalities have, the newsletter always received less than the needed level

\footnotetext{
${ }^{13} \mathrm{http} / / /$ www.belami.rs/danas-je-rodendan-narodnih-novina/ (Accessed June 20, 2019).

${ }^{14}$ In-depth interview conducted by Velibor Petković, Assistantat the Department of Communication and Journalism at the Faculty of Philosophy, University of Nis, November 28, 2018 at the "Narodne novine" offices in Nis.
} 
of funding for the projects to be implemented. However, since the City of Nis has significantly larger funds for these purposes ${ }^{15}$, the newsletter mostly received the funds they asked for or a little less, but still enough for the projects to be carried out, with greater efforts and some savings. Given that "Narodne novine" is the only daily newspaper reporting on the news from this region, they are convinced that local governments should provide more funds for them. They also said that they used the funds allocated by the Ministry of Culture and Information of the Republic of Serbia.

With regard to technical and technological capacities of "Narodne novine", the editor said that technology is constantly advancing, and that they never have enough of everything, but they do have software editing of newspapers prior to printing, which could be even better if they had more resources for these purposes. Therefore, there are no existential crisis for the newsletter, the business results are positive, salaries are regular, but they are below the national average. However, they do have staff issues. The editor Stojanovic says: "I wouldn't call it an issue, but we do have staff-related problems: the fact is that the quality is always better if there are more employees, primarily journalists.

"When it comes to the public interest, editor Stojanovic claims that "Narodne novine" benefit the public interest of the local community. Journalists report on all major events in the city and region and strive to report as objectively as possible, in a clear and understandable manner. She also points out that there are no topics that are not of public interest, as some polls have shown that citizens want to read about, "the ordinary topics about ordinary people, what they do, how they live, what happens to them, and not just about politics and celebrities". This newspaper reports on topics of public importance, and it has columns that talk about politics, economy, society, but also about culture and sports, Stojanovic says. Regarding the capacity and plans for the further development of online edition, Stojanovic points out that new technologies have enabled faster and easier work, but this has also led to a reduction in the number of employees in the newspaper. "Narodne novine" do not have a separate editorial board for the online edition, and the online edition is identical to the print one. Therefore, the editor recognizes the opportunity to further improve the online edition. Technological development should bring innovation and improve communication with readers and as well as the interaction between them and the media, Stojanovic points out.

As for the development strategy, the editor Stojanovic also points out that "Narodne novine" newsletter is being able to survive, and it must keep doing that because it is absolutely necessary... This newspaper is needed on a daily basis to inform citizens, but also as archival material, because when monographs are written about certain institutions, our newsletter provides all the information necessary. Rarely does anyone have their own archive."

\footnotetext{
${ }^{15}$ This year, the city allocated the record amount of 79 million dinars for media projects, which is 25 million more than the previous year. Up to 15 million dinars are estimated per project. Available at: https://www.juznevesti.com/Ekonomija/U-Nisu-i-do-15-miliona-dinara-za-medijske-projekte.sr.html (Accessed August 20, 2019).
} 


\section{Methodological framework}

The subject of this paper's research is journalistic practice in the "Narodne novine" newspaper in two socio-historically different periods, which further explains the transformation of local print media. The goal is to investigate how the "Narodne novine" newspaper has transformed itself in relation to genre, and in thematic and visual terms.

In this regard, the authors apply quantitative and qualitative content analysis using a comparative and synthetic research method. The research corpus consists of 63 articles from two editions of "Narodne novine" - the newspapers published on May $1^{\text {st }} 1949$ ( 28 articles) and 70 years later, on May $1^{\text {st }} 2019$ ( 35 articles). The corpus consists of all the contents published in these two issues.

SPSS for Windows, version 15.0 was used for data entry and analysis, while the statistical procedure used was descriptive statistics (frequency distributions and cross-tabulations).

\section{Research results and discussion}

Quantitative and qualitative content analysis, based on the code sheet, explored the following characteristics of the two issues of the daily that were the subject of the analysis.

The length of the article (text) was determined by the coverage of the newspaper page. Short articles consisted of a few sentences, medium articles covered up to one third of the page, while a long article was considered the one which covered a half of the page or more. The results of the analysis showed that the 1949 edition had more shorter articles, while the 2019 edition primarily included medium-sized articles. The results are presented in Table 1.

Table 1 The length of the article "Narodne novine" May $1^{\text {st }} 1949$ and May $1^{\text {st }} 2019$.

\begin{tabular}{cccc}
\hline & Short article & Medium article & Long article \\
\hline${\text { May } 1^{\text {st }} 1949}^{\text {st }} 2019$ & 19 & 5 & 4 \\
${\text { May }{ }^{\text {st }}}$ & 9 & 18 & 8 \\
\hline
\end{tabular}

The authorship of the articles was also analysed. The results show that the 1949 edition mostly had unsigned articles. There were half the number of articles citing the author by the full name and surname, or by the first letter of the name and the surname. The least number of articles were signed by initials. This has changed in 2019: most of the texts were signed with initials. There were also many unsigned articles, which was also the case in 1949, even though this is not in line with the current Code of Serbian Journalists ${ }^{16}$. The results are shown in Table 2 in a tabular

\footnotetext{
${ }^{16}$ Available at: http://www.savetzastampu.rs/doc/Kodeks_novinara_Srbije.pdf(Accessed August 20, 2019).
} 
format. One article in the 1949 edition of the "Narodne novine" newsletter was signed by the Communist Party of Yugoslavia, and it is presented in the column titled other.

Table 2 Authorship of the articles "Narodne novine" May $1^{\text {st }} 1949$. and May $1^{\text {st }} 2019$.

\begin{tabular}{cccccc}
\hline & $\begin{array}{c}\text { Signed } \\
\text { articles }\end{array}$ & $\begin{array}{c}\text { Articles } \\
\text { signed by } \\
\text { initials }\end{array}$ & $\begin{array}{c}\text { News } \\
\text { agency } \\
\text { articles }\end{array}$ & $\begin{array}{c}\text { Unsigned } \\
\text { articles }\end{array}$ & Other \\
\hline May 1 1949 & 8 & 3 & 0 & 16 & 1 \\
May 1 $1^{\text {st } 2019}$ & 3 & 19 & 1 & 12 & 0 \\
\hline
\end{tabular}

In the issue of "Narodne novine" published on May $1^{\text {st }} 1949$, there were 11 articles which talked about the south of Serbia, and not solely about Nis. Three of the published articles spoke about Prokuplje, two talked about Aleksinac, Vranje and Jelašnica each, while one article reported on Hum and one on Donja Toponica. Only one article more reported on the topics from Nis. Seventy years later, the same newspaper primarily reports on topics relating to Nis and less to other towns from the south of Serbia. Žitkovac, Doljevac, Kursumlija, Prokuplje and Svrljig had an article each reporting on the topics from these towns. Most of the texts talk about Nis, and there are also significantly more articles reporting on national and international topics - mostly unsigned, which may suggest that they were taken over from national media. The results are shown in Table 3 in a tabular format.

Table 3 Locality of topics of text "Narodne novine" May $1^{\text {st }} 1949$. and May $1^{\text {st }} 2019$.

\begin{tabular}{cccccc}
\hline & $\begin{array}{c}\text { National } \\
\text { topics }\end{array}$ & $\begin{array}{c}\text { Topics from } \\
\text { Nis }\end{array}$ & $\begin{array}{c}\text { South od } \\
\text { Serbia }\end{array}$ & $\begin{array}{c}\text { International } \\
\text { topics }\end{array}$ & $\begin{array}{c}\text { General } \\
\text { topics }\end{array}$ \\
\hline May $1^{\text {st }} 1949$ & 3 & 12 & 11 & 2 & 0 \\
May $1^{\text {st }} 2019$ & 5 & 18 & 5 & 6 & 1 \\
\hline
\end{tabular}

As for the complexity of the articles, 2019 ones are much more complex. More texts have more complete title blocks, meaning that except titles they have headings and subheadings. While in 2019 more than 70 percent of articles contained photographs, often more than one, in 1949 less than 40 percent of articles contained any photographs. There is less illustration and no snippets or graphics. Beside this, most pages of the 2019 edition are in colour, while the 1949 edition of "Narodne novine" is black and white, while red ink was used only twice - at the beginning and at the very end of the newspaper, in order to highlight the headline of the newspaper and the slogan "Long live the five-year plan - the basis of socialism in our country!". The results are shown in Table 4 and Table 5 in a tabular format. 
Table 4 Complexity of the articles "Narodne novine" May $1^{\text {st }} 1949$.

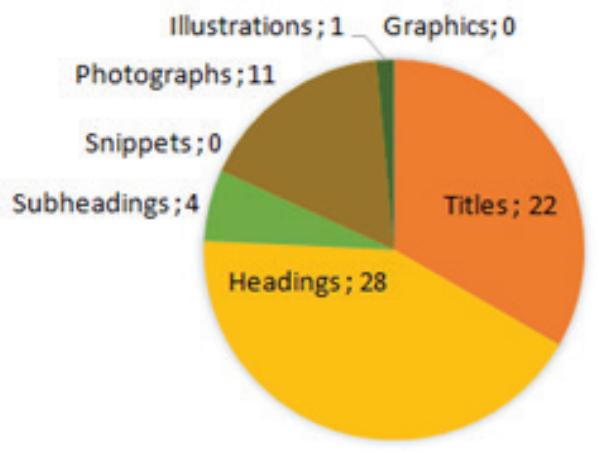

Table 5 Complexity of the articles "Narodne novine" May $1^{\text {st }} 2019$.

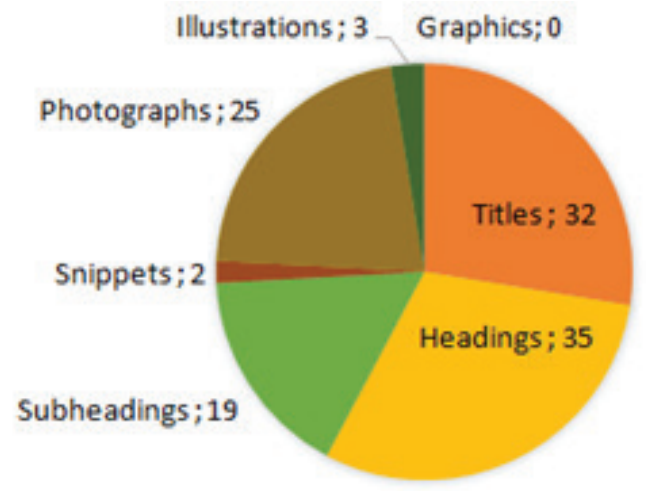

The topics that journalists covered in 1949 and 2019 are shown in Table 6 and Table 7. In both years, most topics were related to society. In 1949, the most prominent topics were related to politics, economy and culture. There was no general, regionrelated information, as well as no local crime news, unlike the 2019 issue. The 2019 issue includes sports articles, while economy-related topics are not addressed. It is interesting to note that there are no entertainment-related articles in any of these editions.

Table 6 The topics that journal covered "Narodne novine" May $1^{\text {st }} 1949$.

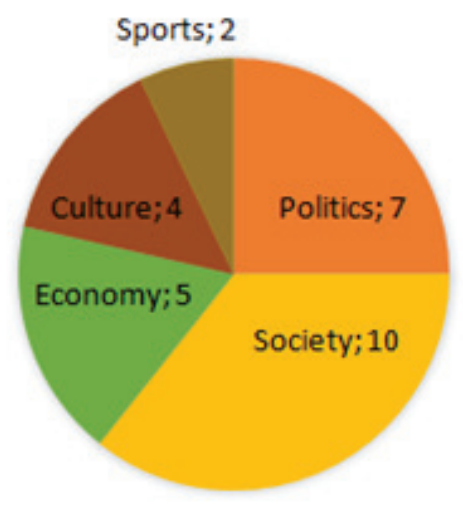


Table 7 The topics that journal covered "Narodne novine" May $1^{\text {st }} 2019$.

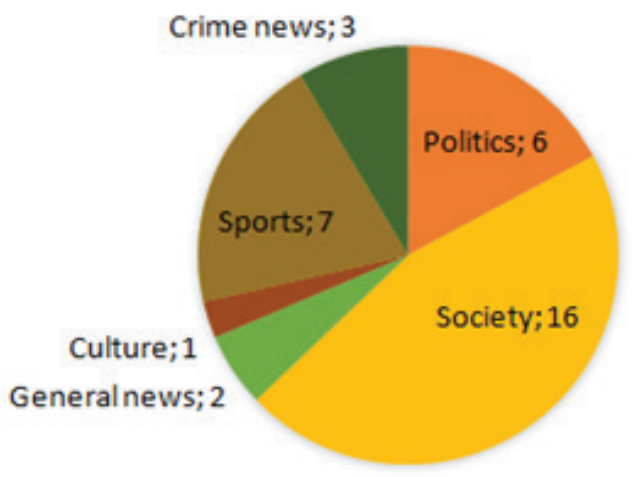

The diversity of genres is shown in Table 8 and Table 9. In both of these issues analysed, the majority of articles included news and reports. Both editions have published articles and a comment. The 2019 edition of "Narodne novine" is more diverse in genre due to the published photo-report entitled Easter in Nis.

Table 8 Genres “Narodne novine” May $1^{\text {st }} 1949$.

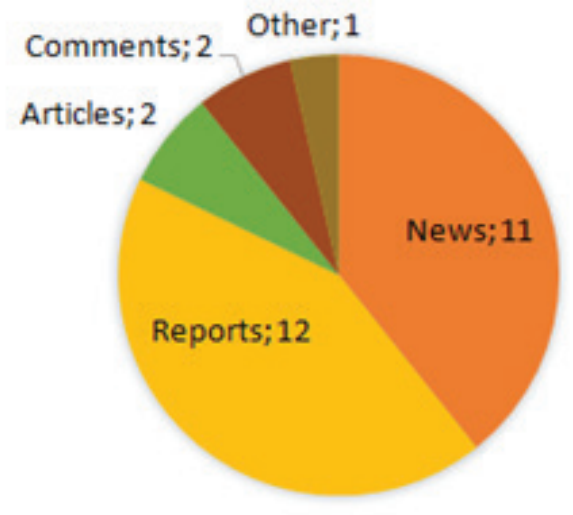

In addition to the genres in the analysed issue from 1949, illustrated in Table 8 there was one article which talked about the anniversary of the Communist Party of Yugoslavia in the form of a welcome speech, but it cannot be classified into any genre category (it is marked in the chart as "other"). Such content was also published in the 2019 issue regarding Easter customs. 
Table 9 Genres “Narodne novine” May $1^{\text {st }} 2019$.

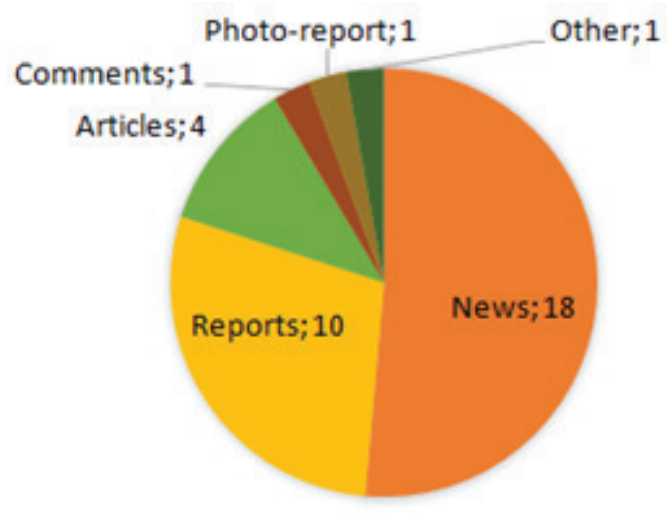

In addition to the differences shown in the tables, the difference between the 1949 and 2019 issues is also apparent in the cover pages. The front page of the modern edition is printed in colour, has four titles, three of which contain photographs. It also contains a caricature. On the other hand, the front page of the 1949 newspaper contains a text signed by the Central Committee of the Communist Party of Yugoslavia, and the only photograph on it is a portrait of Josip Broz Tito. Due to it being the holiday issue, the 2019 newsletter had several pages that included advertisements, May Day greetings from city and municipal institutions, public utility companies and trade union organizations, which were not included in the socialist period newspaper issue. Contemporary "Narodne novine" also prints small advertisements, a price list for advertising and obituaries. In addition to the legally binding impressum which the both analysed issues contain, the 2019 newspaper also includes a daily horoscope, a television guide, a guide to city services and organizations, and a weather forecast.

\section{Conclusion}

Local newspapers are a testimony to life in local communities, and they differ from other types of media because they cover specific local topics and content that are important for decision making by citizens of a certain community. In fact, to research a local newspaper means to feel the pulse of a society and its dynamics, which is also evident from the study of "Narodne novine", a daily news and political newspaper with the longest publication time in south-eastern Serbia, which is at the same time the only daily newspaper published south of Belgrade.

The analysis of the transformation of a newsletter in relation to genre, and in thematic and visual terms during the two socially and historically different periods gives a special insight not only into the similarities and differences, as well as the characteristics of the print media in the analysed periods, but it also gives insight into the specifics of these two historical periods and their social impact on the media, and indirectly on the audience. Based on the analysis, we can conclude that the 
current issues of "Narodne novine" are significantly visually richer than the first issue under this name. Moreover, the visual content of modern "Narodne novine" has a greater degree of communicability, which results from the use of colour. Due to the simplification of colour printing technology, "Narodne novine" has transformed from a newspaper that used exclusively black and red 70 years ago to colour newspapers as we know it today. Nevertheless, the title of this newspaper is still coloured red, as it was the case in the first issue, but its intensity has been increased. Colour printing was the requirement of the audience, who are becoming more visual as a result of the overall media transformation. In addition to the difference in visual richness of the newspaper, there is a slight difference in the genre structure. Compared to the first issue of this newspaper, "Narodne novine" of 2019 is more diverse in genre. Photoreports contribute to the diversity of the genres, which supports the abovementioned statement regarding the response of the "Narodne novine" to the visual demands of their readers. However, the dominant genres found in the both analysed issues are news and reports. It is interesting to mention that no interviews were published in any of the analysed issues. The analysis thus leads to the conclusion that this printed newspaper has not embraced the genre hybridization, that is, genre blending in media, thus one can clearly identify "pure" genres in this newspaper, which was also the case in the socialist period. Furthermore, the current issues of "Narodne novine", unlike older editions, cover national and international topics, in addition to the local ones. This result supports the fact that today it is much easier to quickly get up-to-date and verified national and international information, both due to the use of the Internet and numerous international media agencies. However, it is particularly interesting to note that the analysed number of "Narodne novine" published in 1949 contains more local stories from the south of Serbia, which are actually not focused on the largest city of this part of Serbia - Nis. Moreover, the 1949 issue not only brought more local stories, but they also come from numerous local communities. This points to the current tendency of centralization, which is not found in media only, but can also be identified in other social spheres, such as politics, economy, culture, sport.

The comparative analysis of the "Narodne novine" issue of 1949 and the issue published 70 years later, in 2019 , clearly shows that this newspaper has responded to the demands of the audience, which are conditioned by the progress and development of media technologies. Visual content quality has very much improved and the newsletter has become more attractive and modern. The genre structure has slightly changed, but the focus is still on the factographic genre. The newspaper now covers more national and international news, however, there are less and less news covering topics from small towns. This observation clearly indicates that it is necessary to increase the amount of decentralized news, which would significantly improve both this local media and life in smaller communities. Without developed media, there is no development of a democratic society. Local media are a particularly important link in this process, as they can directly influence the strengthening of democracy, as well as the social and political participation of Serbian citizens. 


\section{References}

Costera Meijer, I. (2010). “Democratizing Journalism? Realizing the Citizen's Agenda for Local News Media”. Journalism Studies, 11(3), pp. 327-342.

Dedić, N. (2009). Ka radikalnoj kritici ideologije: Od socijalizma ka postsocijalizmu. Beograd: Prodajna galerija Beograd.

Đorđević, D., Radulović, L. M. (2012). "Pogranične opštine jugoistočne Srbije u štampanim medijima - primer Narodnih novina”. Teme 4/2012, pp. 1583-1611.

Izveštaj o pritiscima i kontroli medija u Srbiji, (2011). Adopted by the Savet za borbu protiv korupcije on 2011. Available on: http://www.antikorupcija-savet.gov.rs/Storage/ Global/Documents/mediji/IZVESTAJ\%20O\%20MEDIJIMA,\%20PRECISCENA\%20 VERZIJA.pdf, (Accessed June 20, 2019).

Janjetović, Z. (2011). Od Internacionale do komercijale: popularna kultura u Jugoslaviji 1945-1991. Beograd: Insitut za noviju istoriju Srbije.

Krstić, S. (2016). Novine i novinari. Niš: Udruženje novinara Srbije i Filozofski fakultet Univerziteta u Nišu.

Matić, D. (2012). "Strukturni uzroci krize informativne štampe u Srbiji”. Godišnjak FPN, 6/8, pp. 167-182.

Mihajlov, M. (1968). “Why We Are Silent”. Quadrant 9/6, pp. 13-17.

Mihajlov Prokopović, A. (2014). "Local media in Serbia within new media laws". Facta Universitatis - Philosophy, Sociology, Psychology and History, (3), pp. 95-109.

Milivojević, S. i Mihailović, S. (2005). Lokalni mediji u Srbiji i razvoj lokalne zajednice. Beograd: Fondacija Friedrich-Ebert.

Mirčetić, D. (1972). Niška štampa 1871-1971, istorijsko bibliografski prilozi. Niš: Gradina.

Nielsen, R.K. (Ed.) (2015). Local Journalism: The decline of newspaper and the rise of digital media. Bloomsbury Publising.

Radojković, M. (1984). Savremeni informaciono-komunikacioni sistemi. Beograd: Zavod za udžbenike i nastavna sredstva.

Radojković, M. (2007). “Put lokalne zajednice u informaciono društvo”. CM Communication and Media, 2(2), pp. 45-59.

Tomić, B. (2007). “Opseg privatizacije masmedija u Srbiji”. CM Communication and Media, 2(5), pp. 55-76.

Veljanovski, R. (2009). “Mediji i država u tranziciji”. Godišnjak FPN 3/3, pp. 363-378.

Veljanovski, R. (2017). Vlasnička transformacija lokalnih medija u Srbiji, razlozi i otpori. (Ed). R. Veljanovski. Lokalni mediji posle vlasničke transformacije i javni interes, (pp. 9-19). FPN

Kodeks novinara Srbije. Available on: http://www.savetzastampu.rs/doc/Kodeks_ novinara_Srbije.pdf (Accessed August 20, 2019). 


\title{
„NARODNE NOVINE”: ŽANROVSKA, TEMATSKA I VIZUELNA TRANSFORMACIJA 1949-2019.
}

\begin{abstract}
Značaj lokalnih medija je neupitna za teoretičare medija i medijsku praksu, uprkos sveobuhvatnoj globalizaciji. Iako najveću publiku imaju elektronski, a trend rasta onlajn mediji, tradicionalni štampani mediji još opstaju $i$ utiču na politički i društveni život lokalnih zajednica. "Narodne novine” su dnevni infarmativno-politički list sa najdužom tradicijom izlaženja u jugoistočnoj Srbiji. Autorke u radu, koristeći kvantitativnu i kvalitativnu analizu sadržaja, komparativni $i$ sintetički metod, istražuju kako su se novine transformisale $u$ žanrovskom, tematskom $i$ vizuelnom smislu kroz dva društveno-istorijski drugačija razdoblja, u socijalističkom i tranzicijskom periodu. Korpus istraživanja čini 63 priloga iz dva izdanja "Narodnih novina" - brojeva objavljenih 1. maja 1949. godine (njih 28) i 70 godina kasnije, 1. maja 2019. godine (35 priloga).
\end{abstract}

Key words: lokalni mediji, štampa, „Narodne novine”, socijalizam, tranzicija 